\title{
VITAMIN A AND $\beta$-CAROTENE LEVELS DURING PREGNANCY IN GAZIANTEP, TURKEY
}

\author{
Iclal Meram ${ }^{1}$, Ali Ihsan Bozkurt ${ }^{2}$, Sahin Killncer ${ }^{1}$, Birgül Ozcirpici ${ }^{3}$, Servet Ozgur ${ }^{3}$ \\ Gaziantep University, Medical Faculty, Turkey: Department of Biochemistry ${ }^{1}$, Department of Public Health ${ }^{3}$; Pamukkale \\ University, Medical Faculty, Turkey: Department of Public Health ${ }^{2}$
}

\begin{abstract}
Summary: Vitamin A levels during pregnancy have important influences on the health of pregnant women and the growing fetus. Therefore, plasma vitamin A and $\beta$-carotene concentrations during pregnancy in Turkish women living in Gaziantep city were investigated in a prevalence study. Optimum sample size was determined as 252 for vitamin A deficiency and vitamin A and $\beta$-carotene levels were examined in 427 pregnant women aged 14-44 years. Vitamin A and $\beta$-carotene concentrations were measured spectrophotometrically by Neeld Pearson method. Vitamin A and $\beta$-carotene concentrations in pregnant women were found as $1.14 \pm 0.44 \mu \mathrm{mol} / \mathrm{L}$, and $1.80 \pm 0.66 \mu \mathrm{mol} / \mathrm{L}$, respectively. Plasma vitamin A concentrations were found in low levels $(<1.05 \mu \mathrm{mol} / \mathrm{L})$ in $45.5 \%$ of pregnant women. Vitamin A deficiency $(<0.7 \mu \mathrm{mol} / \mathrm{L})$ was determined in $16.9 \%$ of pregnant women. A mild negative correlation was obtained between the vitamin A concentration and pregnancy period. Vitamin A levels of pregnant women were decreased significantly in the third trimester $(p<0.05)$. The findings of present study suggest that vitamin A levels of pregnant women were poor in the region. Therefore, the intake of vitamin A with foods should be improved. Supplementation of vitamin A might benefit at improving maternal and child health especially in high-risk groups especially in developing countries. Monitoring vitamin A levels in pregnant women is very important for also determining low and high levels.
\end{abstract}

Key words: Vitamin A; $\beta$-carotene; Pregnancy

\section{Introduction}

Vitamins are essential micronutrients required by the body in small amounts. Vitamin A (and $\beta$-carotene, precursor of vitamin A) is one of the most important of them $(5,11)$. Vitamin A deficiency is a serious problem that often leads to blindness or death of children (19). However, it also plays an essential role in pregnancy. Vitamin A plays an important role in cell differentiation and proliferation, in organ development and maturation, in mucus secretion, in preventing the fetus from resorption $(2,9,19,28)$. Vitamin A also affects iron status (it stabilizes cellular and intracellular membrans) $(15,16)$, increases susceptibity to respiratory infections and diarrhoea (23) and increases morbidity and mortality (25). Many studies indicated that vitamin A deficiency during pregnancy is threatening not only for maternal but also foetal health $(10,21,27)$. Vitamin A deficiency has adverse effects on children because the growth and rapid cellular differentiation that occur early in the life are affected by a lack of vitamin A (18).

Different nutritional habits, life style and various regional and socio-economic factors may affect vitamin A levels. In developing countries: vitamin A deficiency is a serious problem in pregnant. The maternal morbidity (anaemia, infections etc.) and mortality is high in Gaziantep region. Therefore, we investigated plasma vitamin A and $\beta$-carotene concentrations during pregnancy in Turkish women living in Gaziantep city. In addition, we examined if supplementation of vitamin $\mathrm{A}$ is needed by pregnant women in this region or not.

\section{Material and Methods}

Study population and design: The study was carried out between 1998-2000 in Gaziantep, Turkey. The average number of births is about twenty thousand per year in Gaziantep. The optimum sample size was estimated to be 252 (supposing the frequency of vitamin A deficiency to be $20 \%, \alpha=0.05, d=0.10$ ).

Thirteen health centres in city province were included to the study. Four centres were not included because of insufficient health personnel (the number of health centres in the city was 17). Twenty-two midwives working in these health centres were chosen for the study. We preferred to choose the midwives who thought that they would cooperate better with us. The number of pregnant women in- 
cluded to study from each health centre was determined by the total number of pregnant women population of each health centre.

Pregnant women (within $3^{\text {rd }}$ trimester) living in each midwives region had participated in our study until we obtained the planned sample size for each health centre. Pregnant women with systemic disease and/or under medication affecting the level of vitamin A were excluded from the study. Especially pregnant women within $3^{\text {rd }}$ trimester were included to study but also pregnant women within $1^{\text {st }}$ and $2^{\text {nd }}$ trimester were enrolled to study for the evaluation of change of vitamin A levels during pregnancy.

Laboratory Methods: At first, data about pregnant women and their pregnancy such as age, education, job, weeks of gestation, total number of pregnancy etc. was obtained with a questionnaire by the midwives. After that, $10 \mathrm{ml}$ venous blood samples were provided from each pregnant woman in the morning (between $9^{00-} 10^{30}$ ) after 12 hour fast. Blood specimens were collected in heparinised tube and they were immediately transported (within two hours) to the laboratory in the evacuated container for shielding from the bright light.

Upon arrival at the laboratory, all blood samples were centrifuged (3000 rpm for 10 minutes) and plasma divided in $1 \mathrm{ml}$ aliquots, and stored at $-20{ }^{\circ} \mathrm{C}$ until analysis which was performed in the same run. We observed that vitamin $A$ and $\beta$-carotene concentrations were stable in the plasma pool when they were stored at $-20^{\circ} \mathrm{C}$ for 45 days. The Neeld Pearson method was used for evaluating vitamin $\mathrm{A}$ and $\beta$-carotene concentrations spectrophotometrically (7). Trifluoroacetic acid reacted with the conjugated double bond system of the organic solvent extracted compounds to produce a blue colour (OD:620 nm) by the Neeld Pearson procedure. A correction for the absorbance contribution by carotenes is necessary.

Plasma vitamin A values higher than $1.05 \mu \mathrm{mol} / \mathrm{L}$ were considered as normal range. Plasma vitamin A values lower than $1.05 \mu \mathrm{mol} / \mathrm{L}$ were considered as low and values lower than $0.7 \mu \mathrm{mol} / \mathrm{L}$ were accepted deficiency $(1,13,14)$.

Data were entered to computer and using SPSS statistical package program statistical analysis were performed. In the statistical evaluation of data were used ANOVA and chi square tests.

\section{Results}

In order to evaluate vitamin A levels during pregnancy and its relationship with some conditions of pregnant

Tab. 1: Mean plasma vitamin A and $\beta$-carotene concentrations of pregnant women according to trimesters.

\begin{tabular}{|l|c|c|c|c|}
\hline & $\begin{array}{c}\text { 1. Trimester } \\
(\mathrm{X} \pm \mathrm{SD})\end{array}$ & $\begin{array}{c}2 . \text { Trimester } \\
(\mathrm{X} \pm \mathrm{SD})\end{array}$ & $\begin{array}{c}\text { 3. Trimester } \\
(\mathrm{X} \pm \mathrm{SD})\end{array}$ & $\begin{array}{c}\text { Total } \\
(\mathrm{X} \pm \mathrm{SD})\end{array}$ \\
\hline Plasma Vitamin A level $(\mu \mathrm{mol} / \mathrm{L})$ & $1.21^{*} \pm 0.43$ & $1.20 \pm 0.45$ & $1.10^{*} \pm 0.45$ & $1.14 \pm 0.44$ \\
\hline Plasma $\beta$-carotene level $(\mu \mathrm{mol} / \mathrm{L})$ & $1.71 \pm 0.60$ & $1.87 \pm 0.63$ & $1.81 \pm 0.69$ & $1.80 \pm 0.66$ \\
\hline Number of pregnant women $(\mathrm{n})$ & 97 & 64 & 265 & 426 \\
\hline
\end{tabular}

*The difference between first and third trimester is significantly at the $\mathrm{p}<0.05$ level.

Tab. 2: Mean vitamin A and $\beta$-carotene concentrations of pregnant women according to gestational months.

\begin{tabular}{|l|c|c|c|c|c|c|c|c|}
\hline & $\begin{array}{c}\text { Gestational } \\
\text { Months }\end{array}$ & $\mathrm{n}$ & Mean & Std. Dev. & \multicolumn{2}{c|}{$\begin{array}{c}\text { 95\% Confidence } \\
\text { Interval for Mean } \\
\text { (Lower Bound) }\end{array}$} & Minimum & Maximum \\
\hline & $\leq 2$ & 54 & 1.25 & 0.42 & 1.13 & 1.37 & 0.29 & 2.38 \\
Vitamin A & 3 & 46 & 1.18 & 0.45 & 1.04 & 1.31 & 0.24 & 2.30 \\
& $4-5$ & 59 & 1.21 & 0.44 & 1.09 & 1.32 & 0.30 & 2.16 \\
& $6-7$ & 31 & $0.96^{*}$ & 0.39 & 0.81 & 1.10 & 0.10 & 1.71 \\
& 8 & 101 & 1.14 & 0.42 & 1.06 & 1.22 & 0.13 & 2.32 \\
& 9 & 135 & 1.10 & 0.47 & 1.02 & 1.18 & 0.13 & 2.54 \\
\hline & Total & 426 & 1.14 & 0.44 & 1.10 & 1.18 & 0.10 & 2.54 \\
\hline & $\leq 2$ & 54 & 1.75 & 0.62 & 1.57 & 1.91 & 0.80 & 3.30 \\
& 3 & 46 & 1.68 & 0.58 & 1.50 & 1.85 & 0.78 & 4.07 \\
& $4-5$ & 59 & 1.87 & 0.62 & 1.71 & 2.03 & 0.46 & 3.37 \\
& $6-7$ & 31 & 1.91 & 0.97 & 1.55 & 2.27 & 0.97 & 5.86 \\
& 8 & 101 & 1.82 & 0.65 & 1.68 & 1.94 & 0.52 & 4.01 \\
& 9 & 135 & 1.79 & 0.64 & 1.68 & 1.89 & 0.51 & 3.73 \\
\hline
\end{tabular}

* $p<0.05$ 
women, 427 pregnant women were included to this study. Ninety seven pregnant women were in $1^{\text {st }}$ trimester, 64 were in $2^{\text {nd }}$ trimester and 265 were in $3^{\text {rd }}$ trimester. Mean vitamin $\mathrm{A}$ and $\beta$-carotene concentrations according to trimesters are shown in Tab. 1.

Vitamin A concentration was found as $1.14 \pm 0.44 \mu \mathrm{mol} / \mathrm{L}$ (X+SD), (CI: 1.10-1.18). Mean vitamin A concentration was $1.21 \pm 0.43 \mu \mathrm{mol} / \mathrm{L}$ in the first trimester, $1.10 \pm 0.45$ $\mu \mathrm{mol} / \mathrm{L}$ in third trimester. There was a statistically significant difference in the means of vitamin A between first and third trimesters.

$\beta$-carotene concentration was found as $1.80 \pm 0.66 \mu \mathrm{mol} / \mathrm{L}$ $(\mathrm{X}+\mathrm{SD})(\mathrm{CI}: 1.73-1.86)$. There was no statistically significant for $\beta$-carotene according to trimesters $(p>0.05)$.

Mean vitamin A and $\beta$-carotene concentrations of pregnant women according to gestational months are given in Tab. 2 and Fig. 1. The mean of plasma vitamin A concentration found as $1.25 \mu \mathrm{mol} / \mathrm{L}$ in pregnant women between 1-2 gestational months. With the progress of gestational months, the level of plasma vitamin A decreased and it was reached the lowest value $(0.96 \mu \mathrm{mol} / \mathrm{L})$ in pregnant women between 6-7 gestational months (Fig. 1). It was slightly increased in the last two months of pregnancy. There was statistically significant decrease between the vitamin A levels of pregnant women with lower than 2 months of gestation and the vitamin A levels of pregnant women in 6-7 months of gestation $(p<0.05)$. In addition, there was a mild negative correlation between vitamin A concentration and duration of pregnancy $(r=-0,11)$.

The mean of plasma $\beta$-carotene concentration was found as $1.80 \mu \mathrm{mol} / \mathrm{L}$. There was no statistically significant for $\beta$-carotene according to gestational months $(p>0.05)$, (Tab. 2, Fig. 1). A mild negative correlation was observed between $\beta$-carotene concentration and vitamin A concentration $(r=-0,11)$. As shown Figure $1 ; \beta$-carotene concentration reached the highest value $(1.91 \mu \mathrm{mol} / \mathrm{L})$ in pregnant women between 6-7 gestational months, contrary; vitamin A concentration reached the lowest value at same duration.

Tab. 3: Mean vitamin A and $\beta$-carotene concentrations of pregnant women* according to some conditions.

\begin{tabular}{|c|c|c|c|c|c|c|c|}
\hline & & & & Vitami & $\mu \mathrm{mol} / \mathrm{L})$ & Beta-caro & $(\mu \mathrm{mol} / \mathrm{L})$ \\
\hline & & $\mathrm{n}^{*}$ & $\%$ & Mean & Std.dev & Mean & Std.dev. \\
\hline & $\leq 19$ & 51 & 12.1 & 1.23 & 0.46 & 1.73 & 0.50 \\
\hline & $20-24$ & 151 & 36.0 & 1.14 & 0.43 & 1.79 & 0.71 \\
\hline Age of women & $25-29$ & 113 & 26.9 & 1.09 & 0.44 & 1.82 & 0.68 \\
\hline & $30-34$ & 77 & 18.3 & 1.22 & 0.48 & 1.81 & 0.61 \\
\hline & $\geq 35$ & 28 & 6.7 & 1.04 & 0.33 & 1.80 & 0.67 \\
\hline & Result of analysis & & & & $\mathrm{p}>0.05$ & & $\mathrm{p}>0.05$ \\
\hline & Non-literacy & 67 & 16.0 & 1.16 & 0.48 & 1.91 & 0.74 \\
\hline Education & Literacy & 13 & 3.1 & 1.05 & 0.36 & 1.58 & 0.54 \\
\hline of women & $\begin{array}{l}\text { Graduated } \\
\text { a primary school }\end{array}$ & 301 & 71.8 & 1.14 & 0.44 & 1.78 & 0.64 \\
\hline & $\begin{array}{l}\text { Graduated a secondary } \\
\text { school and more } \\
\text { Result of analysis }\end{array}$ & 38 & 9.1 & 1.17 & $\begin{array}{r}0.44 \\
\mathrm{p}>0.05\end{array}$ & 1.92 & $\begin{array}{c}0.70 \\
\mathrm{p}>0.05\end{array}$ \\
\hline Time interval & $<24$ months & 5 & 1.8 & 1.08 & 0.55 & 1.63 & 0.56 \\
\hline between the & $24-35$ months & 140 & 49.6 & 1.20 & 0.42 & 1.74 & 0.63 \\
\hline previous delivery & 36-47 months & 37 & 13.1 & 1.14 & 0.53 & 1.80 & 0.92 \\
\hline & $\begin{array}{l}\geq 48 \text { months } \\
\text { Result of analysis }\end{array}$ & 100 & 35.3 & 1.14 & $\begin{array}{c}0.44 \\
p>0.05\end{array}$ & 1.87 & $\begin{array}{c}0.66 \\
p>0.05\end{array}$ \\
\hline Total number of & 1 & 120 & 28.6 & 1.08 & 0.44 & 1.80 & 0.58 \\
\hline pregnancy & 2 & 100 & 23.8 & 1.25 & 0.42 & 1.74 & 0.59 \\
\hline & $\geq 3$ & 200 & 47.6 & 1.13 & 0.46 & 1.84 & 0.73 \\
\hline & Result of analysis & & & & $\mathrm{p}<0.05$ & & $\mathrm{p}>0.05$ \\
\hline Job of women & Housewife & 411 & 98.1 & 1.15 & 0.45 & 1.80 & 0.66 \\
\hline & Have a job & 8 & 0.9 & 1.17 & 0.41 & 2.04 & 0.70 \\
\hline & Result of analysis & & & & $p>0.05$ & & $\mathrm{p}>0.05$ \\
\hline Social Insurance & No & 256 & 64.6 & 1.17 & 0.45 & 1,78 & 0.63 \\
\hline & Yes & 140 & 27.3 & 1.13 & 0.43 & 1,94 & 0.76 \\
\hline & Result of analysis & & & & $\mathrm{p}>0.05$ & & $\mathrm{p}>0.05$ \\
\hline Status of smoking & Non-smoker & 384 & 93.9 & 1.15 & 0.44 & 1.81 & 0.67 \\
\hline & Smoker & 25 & 6.1 & 1.15 & 0.45 & 1.67 & 0.62 \\
\hline & Result of analysis & & & & $p>0.05$ & & $p>0.05$ \\
\hline
\end{tabular}

* Women who did not answer were excluded. 
Tab. 4: Evaluation of vitamin A levels compared with normal range in all trimesters.

\begin{tabular}{|c|c|c|c|c|c|c|c|c|}
\hline \multirow{3}{*}{$\begin{array}{c}\text { Vitamin A level } \\
(\mu \mathrm{mol} / L)\end{array}$} & \multicolumn{6}{|c|}{ Pregnancy periods } & & \\
\hline & \multicolumn{2}{|c|}{ I. trimester } & \multicolumn{2}{|c|}{ II.trimester } & \multicolumn{2}{|c|}{ III.trimester } & \multicolumn{2}{|c|}{ Total } \\
\hline & $\mathrm{n}$ & $\%$ & $\mathrm{n}$ & $\%$ & $\mathrm{n}$ & $\%$ & $\mathrm{n}$ & $\%$ \\
\hline Normal $\quad(\geq 1.05)$ & 63 & 64.9 & 37 & 57.8 & 132 & 49.8 & 232 & 54.5 \\
\hline$(<1.05)$ & 34 & $35.0 *$ & 27 & 42.2 & 133 & 50.2 & 194 & 45.5 \\
\hline Deficiency & 11 & 11.3 & 10 & 15.6 & 51 & 19.2 & 72 & 16.9 \\
\hline High deficiency & 2 & 2.1 & 1 & 1.6 & 7 & 2.6 & 10 & 2.3 \\
\hline Total & 97 & 100.0 & 64 & 100.0 & 265 & 100.0 & 426 & 100.0 \\
\hline
\end{tabular}

$* \mathrm{p}<0.05$

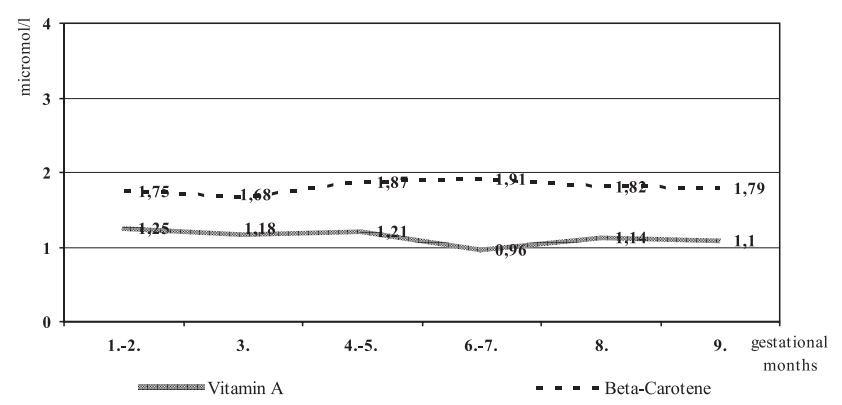

Fig. 1: Mean vitamin A and $\beta$-carotene concentrations of pregnant women according to gestational months.

Both the distributions of pregnant women according to some conditions and the means of vitamin $A$ and $\beta$-carotene concentrations in these groups are given in Tab. 3 .

Age of women, education of women, women's job, time interval between the previous delivery, status of social insurance, status of smoking did not significantly change vitamin $A$ or $\beta$-carotene levels in pregnant women. Only vitamin A concentration in pregnant women who had two pregnancies was significantly higher than other groups $(\mathrm{p}<0.05)$.

The evaluation of mean plasma vitamin A concentrations according to normal range is given in Tab. 4. When the level of plasma vitamin A was evaluated according to normal range, $45.5 \%$ of pregnant women were found in low levels $(<1.05 \mu \mathrm{mol} / \mathrm{L})$. The percentage of pregnant women who had low levels $(<1.05 \mu \mathrm{mol} / \mathrm{L})$ was $35.0 \%$ in the first trimester pregnant women and this rate was significantly lower than $2^{\text {nd }}$ or $3^{\text {rd }}$ trimesters $(\mathrm{p}<0.05)$. This rate was $42.2 \%$ in the $2^{\text {nd }}$ trimester and was $50.2 \%$ in the last trimester.

Vitamin A deficiency $(<0.7 \mu \mathrm{mol} / \mathrm{L})$ was $16.9 \%$ in allpregnant women. The rate of vitamin A deficiency was $11.3 \%$ in the $1^{\text {st }}$ trimester, $15.6 \%$ in $2^{\text {nd }}$ trimester, and $19.2 \%$ in the $3^{\text {rd }}$ trimester pregnant women.

\section{Discussion}

Vitamins are essential micronutrients required in small amounts. Vitamin A (and $\beta$ carotene, precursor of vitamin A) is an antioxidant vitamin and its deficiency is likely to reduce defence against free radical damage (2).
Vitamin A has important influences on the health of pregnant women, growing fetus $(2,3)$. Vitamin A plays a role in reproduction, cell differentiation, proliferation, organ development and maturation $(9,13,23)$. Recent studies show that low plasma vitamin A concentrations and infections are closely associated and common among pregnant women (17). In addition improving vitamin A levels improves haematological indices in both children and pregnant women (15). Recently, a large clinical trial in lowland Nepal, showed that supplementation of pregnant women with BetaCarotene or vitamin A could reduce maternal mortality by $30-50 \%$ (26).

For these reasons, the determination of maternal vitamin A status is important. If there was a deficiency maternal, nutrition should be improved. An intake of $800 \mathrm{RE}$ of vitamin $\mathrm{A}$ is recommended in the non-pregnant women. Extra vitamin A has been recommended during pregnancy. However, because vitamin A excess during pregnancy may be teratogenic, supplementation has been approached with caution and an increased intake of vitamin A- containingfoods suggest instead (8). In addition, vitamin A supplementation might apply to high-risk groups.

Vitamin A levels of pregnant women showed differences regarding to countries and regions. In developed countries: intake of vitamin A and vitamin A levels are occasionally adequate. Vitamin A deficiency was rare in industrial populations therefore; routine supplementation was not required $(6,8,20)$. Plasma vitamin A levels was reported between 2,08-2,15 $\mu \mathrm{mol} / \mathrm{L}$ in Canadian pregnant women (8). These results are higher than our results $(1.14 \mu \mathrm{mol} / \mathrm{L})$. However, there are different studies. The studies carried out in the various social groups in Brazil, Japan, and Spanish reported that pregnant women had a risk for vitamin A deficiency $(12,13,22)$. The ratio of pregnant women with serum vitamin A concentrations $<1.05 \mu \mathrm{mol} / \mathrm{L}$ during the third trimester was $22 \%$ in Spain (13). This rate was lower than our results. These studies suggest that the identification of high-risk populations of pregnant women is important to determine groups who might benefit from vitamin A interventions aimed at improving maternal and child health (16). Vitamin A deficiency is a major public health problem in many developing countries and has been associated with increased morbidity and adverse birth outcomes among pregnant women (24). In a study which was carried 
Africa; $86.6 \%$ of pregnant women had serum vitamin A concentrations $<1.05 \mu \mathrm{mol} / \mathrm{L}$. Our study was done in Gaziantep, Turkey. There were a few performed studies in our country. The mean vitamin_A concentration during the third trimester was slightly lower than that reported by Açkurt et al (1.4 $\mu \mathrm{mol} / \mathrm{L}),(1)$. These authors found that $1.2 \%$ of subjects had serum vitamin A concentrations $<0.35$ $\mu \mathrm{mol} / \mathrm{L}$, and $20.9 \%$ had concentrations $<1.05 \mu \mathrm{mol} / \mathrm{L}$. Our findings were similar and these percentages were $2.6 \%$ and $19.2 \%$ respectively.

The mean vitamin A concentration $(1.14 \mu \mathrm{mol} / \mathrm{L})$ is close to cut-off level of vitamin A $(<1.05 \mu \mathrm{mol} / \mathrm{L})$. The ratio of pregnant women with serum vitamin A concentrations $<1.05 \mu \mathrm{mol} / \mathrm{L}$ during the third trimester was $50 \%$. The ratio of pregnant women with serum vitamin A concentrations $<0.7 \mu \mathrm{mol} / \mathrm{L}$ during the third trimester was $16.9 \%$ which is considered to be vitamin A deficiency.

These findings suggest that the vitamin A level of pregnant women in Gaziantep region is often deficient during pregnancy. Only eight $(1.8 \%)$ of the subjects in this study had excessive vitamin A levels (between 2,10-2,54 $\mu \mathrm{mol} / \mathrm{L}$ ). Supplementation with vitamin A may be preferred in our region.

The role of vitamin $\mathrm{A}$ in haematopoiesis is known. Vitamin A deficiency inhibits iron utilization and accelerates the development of anaemia. Anaemia in pregnant women was common in Gaziantep region. The anaemia rate was reported as 32\% in pregnant women in Gaziantep city (4). This rate was increased to $41 \%$ in $3^{\text {rd }}$ trimester pregnant women. One of the reasons of high rates of anaemia in pregnant women in Gaziantep region may be vitamin A deficiency in pregnant women.

\section{Conclusions}

Monitoring and improving the vitamin A status during pregnancy may help maternal health and the development of fetus (for also low and high levels). The vitamin A level of pregnant women in Gaziantep region is often deficient during pregnancy as accepted most of the developing countries. So vitamin A levels must be monitored in pregnant women and adequate vitamin A intake should be improved by dietary counselling in these countries. Supplementation with vitamin A may be preferred way of assuring adequate vitamin $\mathrm{A}$ intake in these countries especially for risk-groups.

\section{Acknowledgements}

Gaziantep University Research Foundation supported this study and it was represented as an abstract in $18^{\text {th }}$ International Congress of Biochemistry and Molecular Biology (July 2000, Birmingham,UK).

\section{References}

1. Ackurt F, Löker M, Welherilt $\mathrm{H}$. Pre ve postnatal dönemdeki annelerin besin düzeylerinin degerlendirilmesi (Evaluation of pre and postnatal nutrition status of mothers). Nutr Diet 1996;25:5-15.
2. Asworth CJ, Antipatis C. Micronutrient programming of development throughout gestation. Reproduction 2001;122:527-35.

3. Black RE. Micronutrients in pregnancy. Br J Nutr 2001;85:193-7.

4. Bozkurt A, Meram I, Ahi S, Ozcırpıcı B, Özgür S. The investigation of some haematological parameters in pregnant women in Gaziantep. Dicle Med J 2000;25:170-6.

5. Brewster MA. Vitamins. In: Kaplan LA and Pesce AJ eds. Clinical Chemistry. 3rd ed. Philadelphia, USA: C.V. Mosby, 1996:760-93.

6. Chaxla PK, Pari R. Impact of nutrional supplements on hematological profile of pregnant women. Indian Pediatr 1995;32:976-80.

7. Donald S, McLaren MD. Sight and Life: Manual on vitamin A Deficiency Disorders. Philadelphia: Task Force, 2000:8-13.

8. Godel JC, Basu TK, Pabst HF. Perinatal vitamin A [retinol] status of northern Canadian mothers and their infants. Biol Neonate 1996;69:133-9.

9. Hofmann C, Eichele G. Retinoids in devolepment. In: Sporn MB, Roberts AB Goodman DS eds. The retinoids. New York: Raven Press, 1994:387-435.

10. Kayaalp SO. Tibbi Farmakoloji (Medical Pharmocology), 8 th ed. Ankara: Hacettepe Tas Kıtapçılık, 1998:1530.

11. Mc Cormick DB, Green HL. Vitamins. In: Burtis CA, Ashwood ER eds. Tietz Textbook of Clinical Chemistry. 3rd ed. Chapter 29, Philadelphia: WB Saunders Company, 1999:999-1029.

12. Ocampo MB, Moriya K. A comparative study of nutrition and health of mother in Japan and the Philippines. Southeast Asian. J Trop Med Public Health 1997;28:645-56.

13. Ortega RM, Andres P, Martinez RM, Sobaler ML. Vitamin A status during the third trimester of pregnancy in Spanish women: Influence on concentrations of vitamin A in breast milk. Am J Clin Nutr 1997;66:564-8.

14. Pilch SM. Analysis of vitamin A data from the health and nutrition examination surveys. J Nutr 1987;117:636-40.

15. Ramakrishnan U, Manjrekar R, Rivero J, Ganzales T, Martorell R. Micronutrients and pregnancy outcome, a review of the literature. Nutr Res 1999; 9:133-4

16. Semba RD, Muhilal, West KP, Winget M, Natadisastra G, Scott A, Sommer A Impact of vitamin A supplementation on haematological indicators of iron metabolism and protein status of children. Nutr Res 1992;12:469-78.

17. Semba RD, Kumwenda N, Taha TE et al. Plasma and breast milk vitamin A as indicators of vitamin A status in pregnant women. Int J Vitam Nutr Res 2000 70:271-7.

18. Sklan D. Vitamin A in human nutrition. Prog Nutr Sci 1987;11:39-55.

19. Sommer A. Vitamin A deficiency and childhood mortality. Lancet 1992;340: 488-9.

20. Tamura T, Goldenberg RL, Johston KE, Cliver SP, Hoffman HJ. Serum concentrations of zinc, folate, vitamin $\mathrm{A}$ and $\mathrm{E}$ and proteins and their relationships to pregnancy outcane. Acta Obstet Gynecol Scand Suppl 1997;165:63-70.

21. Torfs CP, Lam PK, Schaffer DM, Brand RJ. Association between mothers nutrient intake and their offspring's risk of gastroschisis. Teratology 1998;58:241-50.

22. Trugo NM. Micronutrient regulation in pregnant and lactating women from Rio de Janeiro. Arch Lanoam Nutr 1997;47:30-4.

23. Van den Berg H. Vitamin A intake and status. Eur J Clin Nutr 1996;50:7-12.

24. Wallingford JC, Underwood BA. Vitamin A deficiency in pregnancy, lactation and the nursing child. In: Bauernfeind JD ed. Vitamin A deficiency and it's control. Orlanda: Academic press, 1990:119-23.

25. West KP, Howard GR, Sommer A. Vitamin A and infections, public health implications. Annu Rev Nutr 1989;9:63-86.

26. West KP, Katz J, Khatry SK et al. Double blind,cluster randomised trial of low dose supplementation with vitamin A or beta carotene on mortality related to pregnancy in Nepal. BMJ 1999;318:570-5.

27. Zhang C, Williams MA, Sanchez SE et al. Plasma Concentrations of Carotenoids, Retinol, and Tocopherols in Preeclamptic and Normotensive Pregnant Women. Am J Epidemiol 2001;153:572-80.

28. Zile MH. Function of vitamin A vertebrate embryonic development. Am Soc Nutr Sci 2001;131:705-8.

Submitted September 2003.

Accepted April 2004.

Assist. Prof. Iclal Meram, M.D., Gaziantep University Medical Faculty, Department of Biochemistry, Campus, 27310, PTT Section of University, P.K (Post Box): 39, 27310 Gaziantep, Turkey. e-mail: iclalgeyikli@mynet.com 